\title{
PENGARUH LINGKUNGAN KERJA DAN MOTIVASI KERJA TERHADAP KEPUASAN KERJA KARYAWAN PADA DIREKTORAT UMUM LEMBAGA PELAYANAN PUBLIK TELEVISI REPUBLIK INDONESIA
}

\author{
I Ketut R. Sudiarditha, Agung AWS Waspodo, Nesia Ayu Triani \\ Fakultas Ekonomi Universitas Negeri Jakarta \\ Email: sudiarditha@yahoo.com
}

\begin{abstract}
This study aims to: (1) To determine the effect of the work environment on employee job satisfaction at the General Directorate of Public Services TVRI. (2) To determine the effect of work motivation on employee job satisfaction at the General Directorate of Public Services TVRI. (3) To determine the effect of the working environment and motivation to work together on employee job satisfaction at the General Directorate of Public Services TVRI. The analysis technique used in this study is a simple linear regression analysis and multiple linear regression. Sampling was done by stratified random sampling technique, while the technique of data collection is done by distributing questionnaires, which are then processed using SPSS 19.0. The results showed that: (1) The working environment has a significant impact on job satisfaction. This means that a conducive working environment will be increased job satisfaction. (2) Motivation of work has a significant impact on job satisfaction. This means that high motivation will be able to increase job satisfaction, (3) The work and motivation to work together to have a significant impact on job satisfaction; the influence is $34.9 \%$.
\end{abstract}

Keyswords: work environment, motivation, job satisfaction

\begin{abstract}
Abstrak. Penelitian ini bertujuan untuk: (1) Mengetahui pengaruh lingkungan kerja terhadap kepuasan kerja karyawan pada Lembaga Pelayanan Publik TVRI. (2) Mengetahui pengaruh motivasi kerja terhadap kepuasan kerja karyawan pada Lembaga Pelayanan Publik TVRI. (3) Mengetahui pengaruh lingkungan kerja dan motivasi kerja secara bersama-sama terhadap kepuasan kerja karyawan pada Lembaga Pelayanan Publik TVRI. Teknik analisis yang digunakan pada penelitian ini adalah analisis regresi linear sederhana dan regresi linear berganda. Pengambilan sampel dilakukan dengan teknik stratified random sampling, sedangkan teknik pengumpulan data dilakukan dengan melakukan penyebaran kuisioner, yang kemudian diolah menggunakan SPSS 19.0. Hasil penelitian menunjukkan bahwa: (1) Lingkungan kerja memiliki pengaruh yang signifikan terhadap kepuasan kerja. Artinya Lingkunagn kerja yang kondosif akan tercipta peningkatan kepuasan kerja. (2) Motivasi kerja memiliki pengaruh yang signifikan terhadap kepuasan kerja. Artinya motivasi yang tinggi akan dapat meningkatkan kepuasan kerja. (3) Lingkungan kerja dan motivasi kerja secara bersama-sama memiliki pengaruh yang signifikan terhadap kepuasan kerja; besarnya pengaruh adalah 34.9\%.
\end{abstract}

Kata kunci: lingkungan kerja, motivasi, kepuasan kerja.

\section{PENDAHULUAN}

Kesuksesan merupakan tujuan dari setiap organisasi, baik itu perusahaan maupun instasi pemerintahaan. Kesuksesan juga merupakan sebuah jembatan bagi perusahaan 
untuk tetap mempertahankan apa yang telah didapatkan selama ini. Semua kesuksesan yang didapat tidak lepas dari sumber daya manusia perusahaan itu sendiri; semakin baik sumber daya manusia dikelola, maka akan semakin sukses juga suatu perusahaan. Sumber daya manusia merupakan sumberdaya yang digunakan untuk menggerakkan dan menyinergikan sumberdaya lainnya untuk mencapai suatu tujuan. Tanpa sumber daya manusia, sumberdaya lainya menganggur dan kurang bermanfaat dalam mencapai tujuan perusahaan. Pentingnya sumber daya manusia bagi setiap perusahaan, mengharuskan setiap perusahaan untuk dapat mengelolanya dengan sebaik-baiknya dan seefektif mungkin, sehingga dapat mempertahankan demi kelangsungan perusahaan. Mempertahankan sumber daya manusia yang baik sangatlah sulit, sehingga kepuasan kerja setiap karyawan merupakan salah satu faktor penting yang harus selalu diperhatikan bagi setiap perusahaan. Ada beberapa faktor kepuasan kerja yang harus diperhatikan oleh perusahaan di antarannya gaji yang adil, hubungan dengan rekan kerja, pekerjaan yang menantang, kondisi lingkungan kerja, promosi jabatan, gaya kepemimpinan, penghargaan atas pekerjaan dan sebagainya.

Berdasarkan hasil wawancara, kepuasan merupakan salah satu permasalahan yang dimiliki setiap perusahaan maupun instasi pemerintahan, termasuk pada karyawan sebuah Lembaga Pelayanan Publik Televisi Republik Indonesia (TVRI). TVRI adalah stasiun televisi pertama di Indonesia, yang mulai mengudara pada tanggal 23 Agustus 1962 dan memonopoli siaran televisi di Indonesia sebelum tahun 1989 serta stasiun televisi tertua di Indonesia; satu-satunya televisi yang jangkauannya mencapai seluruh wilayah Indonesia. Saat ini TVRI memiliki 27 stasiun daerah dan 1 (satu) stasiun pusat yang didukung oleh 376 satuan transmisi yang tersebar di seluruh wilayah Indonesia. Berdasarkan hasil pra riset yang telah dilakukan oleh peneliti pada Lembaga Pelayanan Publik TVRI, di mana peneliti mengambil sebanyak 15 responden dari direktorat umum LPP TVRI untuk menjawab 10 pertanyaan yang berhubungan dengan indikator kepuasan kerja, bahwa terdapat kecenderungan beberapa karyawan merasakan ketidakpuasan kerja.

Hasil pra riset yang peneliti lakukan pada karyawan Lembaga Pelayanan Publik TVRI, dapat disimpulkan bahwa terdapat masalah ketidakpuasan kerja pada karyawan. Berdasarkan dua indikator terbesar yang menjadi ketidakpuasan karyawan, di antaranya yaitu indikator fasilitas kerja dan gaji, di mana presentase ketidakpuasan kerja pada indikator gaji sebanyak 33,33\% menyatakan tidak puas dan fasilitas kerja sebesar 33,33\% menyatakan tidak puas; hal ini mungkin disebabkan karena minimnya fasilitas yang tersedia seperti peralatan kantor yang sangat dibutuhkan yaitu komputer yang belum tersedia secara memadai, di mana terdapat beberapa meja karyawan yang tidak terdapat peralatan seperti komputer.

Pada dasarnya kepuasan kerja merupakan masalah besar bagi suatu perusahaan. Tinggi rendahnya kepuasan kerja karyawan akan berakibat terhadap performa karyawan. Hal ini menjadi sebuah permasalahan yang dialami oleh karyawan Lembaga Pelayanan Publik TVRI pada bagian Direktorat Umum. Jika karyawan merasa kebutuhannya telah terpenuhi, maka secara otomatis karyawan akan merasakan kepuasan dan senantiasa memberikan timbal balik berupa kemampuan terbaik yang mereka miliki, serta loyalitas terhadap perusahaan.

Gaji dan fasilitas kerja merupakan salah satu indikator yang mempengaruhi kepuasan kerja karyawan. Kepuasan kerja yang didapat seperti gaji yang sesuai dengan yang diharapkan akan memberikan motivasi kerja untuk dirinya sendiri agar bekerja lebih baik untuk perusahaannya. Tinggi rendahnya motivasi kerja setiap karyawan dapat dilihat 
dari tingkat kepuasan karyawan itu sendiri; semakin puas karyawan terhadap perusahaan, maka akan semakin tinggi juga motivasi mereka dalam menjalankan segala pekerjaanya. Fasilitas kerja yang diberikan juga berhubungan langsung terhadap lingkungan kerja karyawan. Dalam perusahaan, lingkungan kerja juga berhubungan dengan kepuasan karyawan serta hasil yang akan didapat oleh perusahaan. Jika lingkungan kerja nyaman, hal ini akan membantu setiap karyawan dalam menyelesaikan pekerjaannya, dan memberikan kepuasan tersendiri bagi setiap karyawan. Permasalahan lingkungan kerja pada LPP TVRI itu sendiri terletak pada fasilitas kerja yang kurang memadai, sehingga mengakibatkan karyawan kurang efektif dalam berkerja. Fasilitas lainya yaitu, tata letak ruang kerja yang tidak nyaman, di mana jarak meja karyawan yang satu dengan yang lainnya berdekatan, sehingga membuat ruang gerak karyawan sedikit sulit. Selain itu, meja kerja antara karyawan yang satu dengan lainnya tidak diberi sekat pemisah, sehingga membuat kurang leluasa untuk mengerjakan sesuatu. Faktor lainnya yaitu pewarnaan dalam ruangan agak sedikit kusam dan kurang nyaman, hal ini mungkin disebabkan karena keberadaan gedung TVRI yang lumayan sudah berumur. Fasilitas seperti lift perusahaan juga kurang berkerja secara optimal, di mana ada lift yang tidak berfungsi pada saat saya melakukan observasi. Oleh karena itu lingkungan kerja merupakan salah satu faktor yang harus diperhatikan agar memberikan rasa nyaman bagi para karyawan.

Berdasarkan latar belakang permasalahan yang dipaparkan di atas, peneliti melihat ada dua hal yang kemungkinan mempengaruhi kepuasan kerja seorang karyawan yaitu lingkungan kerja dan motivasi kerja. Oleh sebab itu, peneliti terpacu meneliti secara lebih dalam tentang lingkungan kerja dan motivasi kerja serta pengaruhnya terhadap kepuasan kerja karyawan. Hal ini penting untuk dilakukan penelitian dengan judul: Pengaruh lingkungan kerja dan motivasi kerja terhadap kepuasan kerja karyawan pada Direktorat Umum Lembaga Pelayanan Publik TVRI.

Penelitian ini bertujuan untuk: (1) Mengetahui pengaruh lingkungan kerja terhadap kepuasan kerja karyawan pada Lembaga Pelayanan Publik TVRI. (2) Mengetahui pengaruh motivasi kerja terhadap kepuasan kerja karyawan pada Lembaga Pelayanan Publik TVRI. (3) Mengetahui pengaruh lingkungan kerja dan motivasi kerja secara bersama-sama terhadap kepuasan kerja karyawan pada Lembaga Pelayanan Publik TVRI.

\section{KAJIAN TEORI}

Kepuasan Kerja. Kepuasan kerja merupakan faktor penting bagi setiap perusahaan. Kepuasan karyawan diukur dari bagaimana perusahaan memperlakukan setiap karyawannya. Setiap karyawan akan merasa puas apabila seluruh kebutuhan yang mereka harapkan terpenuhi. Tingkat kepuasan setiap individu memiliki tingkat yang berbeda-beda sesuai dengan penilaianya; semakin banyak aspek-aspek yang sesuai dengan harapan, maka semakin tinggi tingkat kepuasan setiap individu. Individu yang merasa puas terhadap apa yang telah didapatkannya akan cenderung memberikan timbal balik yang sesuai dengan apa yang didapatkan, seperti memberikan waktu dan tenaganya untuk suatu perusahaan, dan memiliki motivasi yang tinggi untuk menghasilkan sesuatu yang terbaik. Sebaliknya, individu yang merasa bahwa aspek-aspek yang diinginkan tidak sesuai dengan harapan akan timbul rasa ketidakpuasan yang mengakibatkan motivasi berkurang, bahkan lebih cenderung melakukan hal-hal yang berdampak negatif pada perusahaan, seperi malas berkerja, datang terlambat, jarang masuk kerja dan sebagainya. 
Berbagai definisi tentang kepuasan kerja menurut para ahli, di antaranya yaitu menurut Kreitner dan Kinichi dalam Wibowo (2007) mendefinisikan bahwa "kepuasan kerja merupakan respons affective atau emosional terhadap berbagai segi perkerjaan seseorang”. Menurut definisi ini menunjukkan bahwa job satisfaction bukan merupakan konsep tunggal. Seseorang dapat relatif puas dengan salah satu aspek pekerjaan dan tidak puas dengan satu atau lebih aspek lainnya. Pendapat lain dikemukakan oleh Greenberg dan Baron dalam Wibowo (2007) mendeskripsikan "kepuasan kerja sebagai sikap positif atau negatif yang dilakukan individu terhadap pekerjaan mereka”. Pendapat tersebut hampir sama seperti dikatakan oleh Robbin dan Judge (2008) bahwa "kepuasan kerja (job satisfaction) dapat didefinisikan sebagai suatu perasaan positif dan negatif tentang pekerjaan seseorang yang merupakan hasil dari sebuah evaluasi karakteristiknya”. Seseorang dengan tingkat kepuasan kerja yang tinggi memiliki perasaan-perasaan positif tentang pekerjaan tersebut, sementara seseorang yang tidak puas memiliki perasaanperasaan yang negatif tentang pekerjaan tersebut. Demikian pula bila dilihat dari pendapat ahli lainnya tidak jauh berbeda dikatakan Davis \& Nestrom dalam Wahjono (2008) mendefinisikan bahwa "kepuasan kerja sebagai keadaan emosional yang menyenangkan atau tidak menyenangkan dengan mana karyawan memandang pekerjaan mereka”. Kepuasan kerja mencerminkan perasaan seseorang terhadap pekerjaannya. Hal ini nampak dalam sikap positif karyawan terhadap pekerjaan dan segala sesuatu yang dihadapi di lingkungan kerjanya.

Dalam hal ini, keempat pendapat tersebut sama-sama menekankan pada respon suatu sikap atau perasaan, baik itu positif maupun negatif, bedanya di sini yaitu, Greenberg dan Baron tidak menjelaskan secara jelas dan terperinci tentang apa yang dimaksud dengan sikap positif dan negatif yang dilakukan oleh individu. Berbeda dengan Robbin dan Judge serta Davis dan Nestrom yang menjelaskan secara jelas mengenai perasaan positif yang dirasakan oleh setiap individu terhadap suatu pekerjaan dan segala sesuatu yang di hadapi di lingkungan kerjanya. Namun demikian, lain halnya dikemukakan oleh Robbins dalam Wibowo (2007) dikatakan bahwa "kepuasan kerja adalah sikap umum terhadap pekerjaan seseorang, yang menunjukkan perbedaan antara jumlah penghargaan yang diterima pekerja dan jumlah yang mereka yakini seharusnya mereka terima”. Menurut Robbins, kepuasan kerja yaitu suatu penilaian atau peramalan terhadap apa yang telah merela lakukan, kepuasan akan muncul apabila apa yang mereka dapatkan sesuai dengan apa yang mereka ramalkan atau harapkan, begitu juga sebaliknya.

Berdasarkan beberapa definisi yang dikemukakan oleh para ahli, dapat disimpulkan bahwa kepuasan kerja adalah sebuah keadaan emosional, baik itu positif maupun negatif yang mempengaruhi pekerjaanya, positif jika semua yang aspek yang diinginkan sesuai dengan harapannya; negatif jika semua aspek-aspek yang diinginkan tidak sesuai dengan harapannya.

Lingkungan Kerja. Setiap perusahaan yang didirikan ingin memberikan yang terbaik untuk para karyawan maupun bagi perusahaan. Banyak cara untuk mewujudkan semua itu, salah satunya adalah memberikan lingkungan kerja yang nyaman dan aman bagi seluruh karyawannya. Lingkungan kerja merupakan salah satu hal penting yang harus diperhatikan oleh setiap perusahaan, karena lingkungan kerja merupakan salah satu kunci sukses suatu perusahaan.

Definisi lingkungan kerja berdasarkan para ahli, beberapa di antaranya yang dikemukakan oleh Nitisemito (1992) bahwa "lingkungan kerja adalah segala sesuatu yang ada di sekitar para pekerja dan dapat mempengaruhi dirinya dalam menjalankan tugas 
yang dibebankan”. Baik buruknya lingkungan akan berdampak pada diri karyawan itu sendiri dalam menjalankan tugasnya. Hal ini senada dikatakan oleh Sukanto dan Indriyo dalam Khoiriyah (2009) "lingkungan kerja adalah segala sesuatu yang ada di sekitar pekerja yang dapat mempengaruhi dalam bekerja meliputi pengaturan penerangan, pengontrolan suara gaduh, pengaturan kebersihan tempat kerja dan pengaturan keamanan tempat kerja”. Dalam hal ini, kedua pendapat tersebut bersifat umum yaitu menjelaskan bahwa lingkungan kerja merupakan segala sesuatu yang ada di sekitar pekerja, yang tujuannya sama-sama dapat mempengaruhi diri para pekerja dalam bekerja dan menjalankan tugas-tugasnya. Perbedaannya di sini, Nitisemito hanya menjelaskan sampai sejauh mana lingkungan kerja berpengaruh, sedangkan Sukanto dan Indriyo lebih menjelaskan dalam hal faktor apa saja yang ada di dalam organisasi tersebut seperti pengaturan penerangan, pengontrolan suara gaduh, pengaturan kebersihan tempat kerja dan pengaturan keamanan tempat kerja. Sedikit mirip dengan pendapat yang dikemukakan Triguno dalam Surodilogo (2010) bahwa "lingkungan kerja adalah sarana dan prasarana yang ada di tempat karyawan bekerja dan dapat mempengaruhi karyawan di dalam menjalankan tugas-tugas yang dibebankan”. Dalam hal ini, sama-sama bertujuan dapat mempengaruhi karyawan dalam menjalankan tugas-tugas yang dibebankannya, bedanya yaitu dalam Nitisemito menjelaskan bahwa lingkungan kerja merupakan segala sesuatu yang ada di sekitar pekerja, sedangkan Triguno hanya menjelaskan berupa sarana dan prasarana yang ada di tempat karyawan.

Sedangkan menurut Sudrajat, Kustiawan dan Aipassa (1998) "lingkungan kerja adalah kesatuan ruang yang terdiri atas benda hidup dan benda mati, daya, keadaan yang mempengaruhi kegiatan pekerja dalam menjalankan pekerjaannya”. Pendapat ini menjelaskan bahwa terdapat kesamaan bahwa lingkungan kerja dapat mempengaruhi kegiatan para karyawannya dalam menjalankan dan menyelesaikan pekerjaan. Bedanya di sini yaitu, Triguno menjelaskan apa yang dipengaruhinya seperti sarana dan prasananya, sedangkan Sudrajat, Kustiawan dan Aipassa menjelaskan tentang benda mati dan hidup, daya, dan keadaan yang mempengaruhi karyawan dalam bekerja.

Lain hal pendapat yang dikemukakan oleh Rivai dalam Surodilogo (2010) mendefinisikan "lingkungan kerja merupakan elemen-elemen organisasi sebagai sistem sosial yang mempunyai pengaruh kuat di dalam pembentukan prilaku individu pada organisasi dan berpengaruh terhadap prestasi”. Berbeda halnya menurut Sihombing dalam Patty (2007) "lingkungan kerja adalah faktor-faktor di luar manusia baik fisik maupun non fisik dalam suatu organisasi." Dalam hal ini, lingkungan kerja menurut Rivai dan Sihombing memang sangat berbeda, di mana, Rivai menjelaskan lingkungan kerja merupakan suatu elemen organisasi yang tujuannya yaitu untuk membentuk prilaku yang akan berpengaruh terhadap prestasi, sedangkan Sihombing, menjelaskan lingkungan kerja terdiri dari dua yaitu lingkungan fisik dan lingkungan non fisik dalam suatu organisasi.

Berdasarkan definisi para ahli tersebut, maka dapat diambil kesimpulan, bahwa lingkungan kerja adalah segala sesuatu yang terdapat di sekitar pekerja baik lingkungan fisik (pengaturan penerangan, pengontrolan suara gaduh, pengaturan kebersihan tempat kerja dan pengaturan keamanan tempat kerja), maupun non fisik (hubungan dengan atasan dan bawahan), serta berupa sarana dan prasarana yang ada di tempat kerja yang dapat mempengaruhi pembentukan prilaku dan prestasi para pekerja.

Motivasi Kerja. Seseorang memiliki motivasi cenderung akan memberikan yang terbaik bagi setiap perusahaan. Motivasi yang tinggi didapat dari perlakuan perusahaan terhadap 
karyawan. Jika perusahaan memperlakukan karyawannya sebaik mungkin, maka karyawan akan cenderung memberikan timbal balik yang baik juga untuk perusahaan.

Motivasi berasal dari kata latin movere yang berarti dorongan atau menggerakkan. Terdapat beberapa definisi motivasi seperti yang dikemukakan oleh As'ad dalam Triningsih (2006) "motivasi adalah sesuatu yang menimbulkan semangat atau dorongan kerja”. Motivasi kerja merupakan pemberian atau penggerak yang menciptakan kegairahan kerja seseorang agar mau bekerja sama bekerja secara efektif dan terintegrasi dengan segala daya upaya untuk mencapai kepuasan. Senada seperti dikatakan Pandji Anoraga dalam Triningsih (2006) "motivasi kerja adalah sesuatu yang menimbulkan semangat atau dorongan dan kerja”. Oleh sebab itu, motivasi kerja dalam psikologi sebagai pendorong semangat kerja. Dalam hal ini Pandji Anoraga hanya menjelaskan mengenai motivasi sebagai pendorong, berbeda dengan As'ad, yang mengemukakan secara lebih jelas dan menekankan bahwa motivasi untuk menciptakan suatu kegairahan kerja untuk mencapai suatu kepuasan.

Sedangkan menurut Sarwoto dalam Prabu (2005) mengemukakan bahwa "motivasi adalah sekelompok faktor yang menyebabkan individu berprilaku dalam cara-cara tertentu. Secara konkrit motivasi adalah sebuah proses pemberian motif (penggerak) berkerja kepada para bawahan sedemikian rupa, sehingga mereka mau berkerja dengan ikhlas demi tercapainya tujuan organisasi secara efisien”. Dalam hal ini, mereka samasama menjelaskan bahwa motivasi adalah sebuah alat penggerak; oleh As'ad penggerak yang dimaksud adalah penggerak untuk menciptakan sebuah kegairahan kerja seseorang untuk mencapai suatu kepuasan. Sedangkan dalam Sarwoto, penggerak yang dimaksud adalah penggerak sebagai motif bekerja, sehingga mereka mau berkerja dengan iklas untuk mencapai tujuan suatu organisasi.

Pendapat lainnya dikemukan oleh Robbins (2002) yang mengatakan "motivasi adalah keinginan untuk melakukan sesuatu dan menentukan kemampuan bertindak untuk memuaskan kebutuhan individu”. Berbeda halnya dikatakan oleh Robbins dan Judge (2008) bahwa "motivasi merupakan sebagai proses yang menjelaskan intensitas, arah, dan ketekunan seorang individu untuk mencapai tujuannya. Bila dilihat dari kedua pendapat tersebut memiliki kesamaan maupun perbedaan. Dalam hal kesamaan sama-sama menekankan pada suatu tujuan, di mana Robbins dan Judge tujuan yang dimaksud adalah tujuan individu itu sendiri, sedangkan menurut Robbins tujuan yang dimaksud adalah tujuan dari suatu organisasi.

Sejak dahulu, banyak para ahli yang telah menjelaskan tentang teori-teori mengenai motivasi. Masing-masing para ahli juga memiliki pendapat tentang motivasi yang berbeda-beda, selain itu juga ada beberapa para ahli yang memiliki pendapat yang hampir sama dengan para ahli lainnya. Masing-masing para ahli memiliki referensi yang berbedabeda terhadap teori motivasi. Berikut ini penjelasan beberapa teori tentang motivasi.

Manusia merupakan makhluk sosial yang memiliki perasaan dan kebutuhan, beberapa kebutuhan tersebut merupakan kebutuhan yang harus dipenuhi. Berbagai macam kebutuhan memnyebabkan timbulnya rasa motivasi untuk berusaha memenuhi kebutuhannya. Berbagai teori motivasi seperti: Teori Kebutuhan Maslow, Teori David McClelland, Teori Kebutuhan Clyton Alderfer (Teori ERG). Salah satu teori kebutuhan dalam teori Maslow memiliki tingkatan-tingkatan dari yang paling rendah sampai yang paling tinggi. Berikut penjelasan tentang teori kebutuhan Maslow; menurut Robbins dan Judges (2008), Hierarki Teori Kebutuhan (Hierarchical of Need Theory) milik Abraham Maslow dalam membuat hipotesa mengemukakan bahwa dalam setiap diri manusia 
terdapat hierarki dari lima kebutuhan setiap individu, yaitu: (1) Fisiologis: meliputi rasa lapar, haus, berlindung, seksual, dan kebutuhan fisik lainnya. (2) Rasa aman: meliputi rasa ingin dilindungi dari bahaya fisik dan emosional. (3) Sosial: meliputi rasa kasih sayang, kepemilikan, penerimaan, dan persahabatan. (4) Penghargaan: meliputi faktor-faktor penghargaan internal seperti hormat diri, otonomi, dan pencapaian. Faktor-faktor penghargaan eksternal seperti status, pengakuan, dan perhatian. (5) Aktualisasi diri: Dorongan untuk menjadi seseorang sesuai kecakapannya, meliputi pertumbuhan, pencapaian potensi seseorang dan pemenuhan diri sendiri.

Selain teori kebutuhan Maslow yang dijelaskan dalam Robbins dan Judge, teori Maslow juga dijelaskan oleh Wahjono (2008). Teori kebutuhan Maslow yang hampir mirip dijelaskan oleh Robbins dan Judge yang menghipotesakan bahwa kebutuhan setiap diri manusia terdiri dari lima tingkat kebutuhan yang berjenjang. Bedanya di sini, Robbin dan Judge tidak menjelaskan tentang kebutuhan harga diri seperti yang di kemukakan oleh Wahjono; sementara Robbins dan Judge lebih menjelaskan ke arah penghargaan yang didapat oleh individu tersebut. Berikut lima kebutuhan yang dikemukakan oleh Wahjono, yaitu: (1) Kebutuhan aktualisasi diri dan pemenuhan (self actualization needs). Teoritis: penggunaan potensi diri, pertumbuhan, dan pengembangan diri. Terapan: menyelesaikan penugasan yang bersifat menantang, melakukan pekerjaan kreatif, pengembangan keterampilan. (2) Kebutuhan harga diri (esteem needs). Teoritis: status atau kedudukan, kepercayaan diri, pengakuan reputasi, apresiasi, kehormatan diri, dan penghargaan. Terapan: kekuasaan, ego, promosi, hadiah, status symbol, pengakuan, jabatan, penhargaan. (3) Kebutuhan sosial (social needs).Teoritis: cinta, persahabatan, perasaan memiliki, dan diterima dalam kelompok, kekeluargaan, asosiasi. Terapan: Kelompok kerja formal dan informal, kegiatan yang disponsori perusahaan, acara-acara peringatan. (4) Kebutuhan keamanan dan rasa aman (safety and security needs). Teoritis: perlindungan dan stabilitas. Terapan: Pengembangan karyawan, kondisi kerja yang aman, rencana senioritas, serikat kerja, tabungan, uang pesangon, jaminan pensiun, asuransi, sistem penanganan keluhan. (5) Kebutuhan Fisiologi (physiological needs). Teoritis: Makan, minum, rumah, seks, istirahat. Terapan: ruang istirahat, istirahat makan siang, udara bersih untuk bernafas, air untuk minum, liburan, cuti, balas jasa, dan jaminan sosial, periode istirahat on the job.

Kedua pendapat di atas terdapat beberapa persamaan tentang teori motivasi seperti kebutuhan fisiologis yaitu kebutuhan rasa lapar, haus, rumah dan seks. Kebutuhan sosial yaitu rasa keinginan diterima, rasa memiliki dan kasih sayang. Keinginan untuk mendapat perlindungan dalam kebutuhan keamanan dan pertumbuhan dan pengembangan potensi diri dalam kebutuhan aktualisasi diri. Sedangkan perbedaan terletak pada kebutuhan harga diri yang dijelaskan oleh Wahjono, dan kebutuhan penghargaan yang dijelaskan oleh Robbins dan Judge. Pada dasarnya secara garis besar, kedua pendapat tersebut memiliki arti dan maksud yang sama; hanya saja Robbins dan Jugde tidak menjelaskan secara terperinci seperti apa yang di jelaskan dalam Wahjono.

Berdasarkan definisi di atas maka dapat disimpulkan, motivasi adalah suatu proses menjelaskan intensitas, arah, dan ketekunan individu, serta proses pemberian dorongan atau penggerak kepada seseorang untuk menimbulkan semangat bekerja dan menciptakan kegairahan kerja untuk melaksanakan upaya yang maksimal, sehingga mampu memberikan yang terbaik untuk tujuan individu itu sendiri ataupun tujuan suatu organisasi. 


\section{METODE}

Penelitian dilakukan pada perusahaan televisi negeri yaitu Lembaga Pelayanan Publik Televisi Republik Indonesia. Waktu penelitian dilakukan selama enam bulan mulai Juli 2011 sampai Desember 2011. Populasi pada penelitian ini adalah karyawan pada Direktorat Umum yang terdiri dari beberapa bagian, yaitu: bagian Pengadaan dan Inventarisasi, bagian Sarana dan Prasarana, bagian Sumber Daya Manusia dan bagian Kesekretariatan dan Kelembagaan yang diambil menggunakan Husein (2008) diperoleh 85 orang karyawan sebagai sampel.

Penelitian ini menggunakan metode penelitian eksplanatori. Menurut Sekaran (2007) metode eksplanatori dilakukan jika tidak banyak yang diketahui mengenai siatuasi yang dihadapi, atau tidak ada infromasi yang tersedia mengenai bagaimana masalah atau isu penelitian yang mirip diselesaikan di masa lalu. Teknis analisis yang digunakan Analisis Regresi Linear Berganda dan Analisis Regresi Linear Sederhana.

\section{HASIL DAN PEMBAHASAN}

Hasil Uji Asumsi Klasik. Uji normalitas berguna untuk mengetahui apakah variabel bebas dan variabel terikat dalam penelitian ini keduanya berdistribusi normal, mendekati normal, atau tidak. Model regresi yang baik memiliki distribusi data normal atau mendekati normal. Uji normalitas pada penelitian ini menggunakan uji Kolmogorovsmirnov dan dikatakan normal jika nilai residual yang terdistribusi secara normal memiliki probabilitas signifikansi lebih besar dari 0.05. Hasil uji normalitas menunjukkan bahwa nilai signifikasi untuk variabel lingkungan kerja sebesar 0.053; motivasi kerja sebesar 0.200, dan kepuasan kerja sebesar 0.081. Jadi, variabel lingkungan kerja, motivasi kerja dan kepuasan kerja berdistribusi normal. Hal tersebut karena nilai signifikasi untuk seluruh variabel lebih besar dari 0.05.

Uji multikolinearitas berguna untuk mengetahui apakah pada model regresi ditemukan korelasi kuat antar variabel bebas (independen). Prasyarat yang harus terpenuhi adalah tidak adanya multikolinearitas dalam model regresi. Multikoliniearitas dapat diketahui dengan melihat nilai Variance Inflation Factor (VIF) pada model regresi. Jika besar $\mathrm{VIF}<5$, maka mencerminkan tidak ada multikolinieritas. Berdasarkan hasil multikolinearitas diketahui nilai VIF untuk kedua variabel masing-masing sebesar 1.358. Jadi, dapat disimpulkan bahwa tidak adanya multikolinearitas dalam model regresi yang digunakan, hal ini karena nilai VIF sebesar $1.358<5$.

Uji heteroskedastisitas dilakukan untuk mengetahui apakah dalam sebuah model regresi terjadi ketidaksamaan varian dari residual suatu pengamatan ke pengamatan lain. Jika varian dari residual suatu pengamatan ke pengamatan lain tetap, disebut homokedastisitas, sedangkan untuk varian yang berbeda disebut eteroskedastisitas. Prasyarat yang harus terpenuhi dalam model regresi adalah tidak adanya masalah heteroskedastisitas. Metode yang digunakan dalam penelitian ini adalah metode uji Spearman's rho, yaitu mengkorelasikan nilai residual (unstandardized residual) dengan masing-masing variabel independen. Jika signifikasi kurang dari 0.05, maka terjadi masalah heteroskedastisitas. Hasil uji heteroskedastisitas diketahui korelasi antara lingkungan kerja dengan unstandardized residual menghasilkan nilai signifikasi 
0.513 dan korelasi antara motivasi kerja dengan unstandardized residual menghasilkan nilai 0.507. Jadi, dapat disimpulkan bahwa pada model regresi tidak ditemukan adanya masalah heteroskedastisitas, hal ini karena nilai signifikasi korelasi lebih besar dari 0.05 .

Hasil Pengujian Regresi Linear Sederhana untuk H1 (Uji t). Hasil analisis regresi linear sederhana untuk hipotesis pertama (uji t) dapat dilihat pada Tabel 1 berikut.

Tabel 1. Hasil Uji t Variabel Lingkungan Kerja

\begin{tabular}{cccccc}
\multicolumn{8}{c}{ Coefficients $^{\mathbf{a}}$} \\
\hline \multirow{2}{*}{ Model } & \multicolumn{2}{c}{ Unstandardized } & Standardized & & \\
& \multicolumn{2}{c}{ Coefficients } & Coefficients & t & Sig. \\
& B & Std. Error & Beta & & \\
1 (Constant) & 35.335 & 7.164 & .459 & 4.932 & .000 \\
Lingkungan Kerja & .567 & .121 & & 4.709 & .000 \\
\hline
\end{tabular}

a. Dependent Variable: Kepuasan Kerja

Berdasarkan Tabel 1 tersebut didapat thitung untuk variabel lingkungan kerja sebesar 4.709. Nilai thitung kemudian dibandingkan dengan nilai tabel, yang dicari pada á $=5 \%: 2$ ata u 2,5\% (uji 2 sisi) dengan derajat kebebasan (df) n-k-1 atau 85-2-1, di mana $n$ adalah jumlah sampel dan $\mathrm{k}$ adalah jumlah variabel bebas. Berdasarkan perhitungan tersebut, didapat $t_{\text {tabel }}$ sebesar 1.989, dengan demikian $t_{\text {hitung }}>t_{\text {tabel. }}$ Selain itu, uji hipotesis juga dapat dilakukan dengan melihat signifikasi pada uji $\mathrm{t}$, dimana $\mathrm{H}_{\mathrm{o}}$ ditolak dan $\mathrm{H}_{\mathrm{a}}$ diterima jika signifikasi lebih kecil dari 0.05. Signifikasi pada uji t variabel lingkungan kerja sebesar 0.000, dengan demikian lebih kecil dari 0.05. Kesimpulan yang dapat diambil, $\mathrm{H}_{\mathrm{o}}$ ditolak dan $\mathrm{H}_{\mathrm{a}}$ diterima. Hipotesisnya adalah lingkungan kerja memiliki pengaruh yang signifikan terhadap kepuasan kerja.

Model Persamaan Regresi Linear Sederhana untuk H1. Model persamaan regresi linear sederhana untuk hipotesis 1 berdasarkan tabel tersebut dapat dituliskan sebagai berikut:

$$
\mathrm{Y}=35.335+0.567 \mathrm{X} 1
$$

Berdasarkan model persamaan tersebut, jika variabel lingkungan kerja (X1) bernilai 0, maka variabel kepuasan kerja (Y) akan bernilai 35.335. Koefisien regresi variabel lingkungan kerja (X1) sebesar 0.567. Artinya, jika variabel lingkungan kerja (X1) ditingkatkan sebesar satu satuan, maka kepuasan kerja (Y) akan mengalami kenaikan sebesar 0.567 . Koefisien bernilai positif, artinya terjadi pengaruh positif antara lingkungan kerja terhadap kepuasan kerja.

Hasil Analisis Determinasi $\left(\mathbf{R}^{2}\right)$ untuk H1. Analisis koefisien determinasi $\left(\mathrm{R}^{2}\right)$ dalam regresi linear sederhana digunakan untuk mengetahui seberapa besar persentase pengaruh sumbangan variabel bebas, dalam hal ini variabel lingkungan kerja, terhadap variabel terikat yaitu kepuasan kerja. Hasil uji koefisien determinasi $\left(\mathrm{R}^{2}\right)$ dapat dilihat pada Tabel 2.

Berdasarkan Tabel 2, nilai $\mathrm{R}^{2}$ yang tercantum sebesar 0.211 , nilai itu dapat diinterpretasikan sebagai persentase pengaruh variabel lingkungan kerja terhadap variabel kepuasan kerja yang sebesar 21.1\%, sedangkan 78.9\% dijelaskan oleh faktor lain di luar penelitian. 
Tabel 2. Hasil Analisis Koefisien Determinasi Lingkungan Kerja terhadap Kepuasan Kerja

Model Summary

\begin{tabular}{ccrrr}
\hline Model & $\mathrm{R}$ & R Square & $\begin{array}{c}\text { Adjusted R } \\
\text { Square }\end{array}$ & $\begin{array}{c}\text { Std. Error of the } \\
\text { Estimate }\end{array}$ \\
\hline 1 & $.459^{\mathrm{a}}$ & .211 & .201 & 11.828 \\
\hline
\end{tabular}

a. Predictors: (Constant), Lingkungan Kerja

Hasil Pengujian Regresi Linear Sederhana untuk H2 (Uji t). Hasil analisis regresi linear sederhana untuk hipotesis kedua (uji t) dapat dilihat pada Tabel 3.

Berdasarkan Tabel 3, didapat thitung untuk variabel motivasi kerja sebesar 6.078. Nilai $\mathrm{t}$ hitung kemudian dibandingkan dengan nilai tabel, yang dicari pada á $=5 \%: 2$ atau 2,5\% (uji 2 sisi) dengan derajat kebebasan (df) n- k-1 atau 85-2-1. Berdasarkan perhitungan tersebut, didapat $t_{\text {tabel }}$ sebesar 1.989, dengan demikian $t_{\text {hitung }}>t_{\text {tabel. }}$. Selain itu, uji hipotesis juga dapat dilakukan dengan melihat signifikansi pada uji t. Signifikansi pada uji t variabel motivasi kerja sebesar 0.000 , dengan demikian lebih kecil dari 0,05. Kesimpulan yang dapat diambil, $\mathrm{H}_{\mathrm{o}}$ ditolak dan $\mathrm{H}_{\mathrm{a}}$ diterima. Hipotesisnya adalah motivasi kerja memiliki pengaruh yang signifikan terhadap kepuasan kerja.

Tabel 3. Hasil Uji t Variabel Motivasi Kerja

\section{Coefficients $^{\mathrm{a}}$}

\begin{tabular}{|c|c|c|c|c|c|}
\hline \multirow[t]{2}{*}{ Model } & \multicolumn{2}{|c|}{$\begin{array}{l}\text { Unstandardized } \\
\text { Coefficients }\end{array}$} & \multirow{2}{*}{$\begin{array}{c}\begin{array}{c}\text { Standardized } \\
\text { Coefficients }\end{array} \\
\text { Beta }\end{array}$} & \multirow[t]{2}{*}{$\mathrm{t}$} & \multirow[t]{2}{*}{ Sig. } \\
\hline & B & Std. Error & & & \\
\hline 1 (Constant) & 23.985 & 7.426 & & 3.230 & 002 \\
\hline Motivasi Kerja & .514 & .085 & .555 & 6.078 & 000 \\
\hline
\end{tabular}

a. Dependent Variable: Kepuasan Kerja

Model Persamaan Regresi Linear Sederhana untuk H2. Berdasarkan Tabel 3, dapat diperoleh persamaan regresi linear sederhana untuk hipotesis kedua seperti berikut ini:

$$
\mathrm{Y}=23.985+0.514 \mathrm{X} 2
$$

Berdasarkan model persamaan tersebut, jika variabel motivasi kerja (X2) bernilai 0, maka variabel kepuasan kerja (Y) akan bernilai 23.985 Koefisien regresi variabel motivasi kerja (X2) sebesar 0.514. Artinya, jika variabel motivasi kerja (X2) ditingkatkan sebesar satu satuan, maka variabel kepuasan kerja (Y) akan mengalami kenaikan sebesar 0.514 . Koefisien bernilai positif, artinya terjadi pengaruh positif antara motivasi kerja dengan kepuasan kerja.

Hasil Analisis Determinasi $\left(\mathbf{R}^{2}\right)$ untuk H2. Analisis koefisien determinasi $\left(\mathrm{R}^{2}\right)$ dalam regresi linear sederhana digunakan untuk mengetahui seberapa besar persentase pengaruh sumbangan variabel bebas, dalam hal ini variabel motivasi kerja, terhadap variabel terikat yaitu kepuasan kerja. Hasil uji koefisien determinasi $\left(\mathrm{R}^{2}\right)$ dapat dilihat Tabel 4. 
Tabel 4. Hasil Analisis Koefisien Determinasi Motivasi Kerja Terhadap Kepuasan Kerja (H2)

Model Summary

\begin{tabular}{ccccc}
\hline Model & $\mathrm{R}$ & R Square & $\begin{array}{c}\text { Adjusted R } \\
\text { Square }\end{array}$ & $\begin{array}{c}\text { Std. Error of the } \\
\text { Estimate }\end{array}$ \\
\hline 1 & $.555^{\mathrm{a}}$ & .308 & .300 & 11.076
\end{tabular}

a. Predictors: (Constant), Motivasi Kerja

Berdasarkan Tabel 4, nilai $\mathrm{R}^{2}$ yang tercantum sebesar 0.308. Nilai itu dapat diinterpretasikan sebagai persentase pengaruh variabel motivasi kerja terhadap variabel kepuasan kerja yang sebesar 30.8\%, sedangkan $69.2 \%$ dijelaskan oleh faktor lain di luar penelitian.

Hasil Regresi Linear Berganda untuk H3. Dalam penelitian ini, analisis regresi linear berganda dilakukan untuk mengetahui hubungan secara linear antara dua atau lebih variabel bebas. Adapun hasil regresi linear berganda untuk variabel lingkungan kerja dan motivasi kerja terhadap kepuasan kerja secara parsial dapat dilihat pada Tabel 5.

Tabel 5. Hasil Regresi Linear Berganda

Coefficients $^{\mathrm{a}}$

\begin{tabular}{lcccccc}
\hline \multirow{1}{*}{ Model } & \multicolumn{2}{c}{$\begin{array}{c}\text { Unstandardized } \\
\text { Coefficients }\end{array}$} & $\begin{array}{l}\text { Standardized } \\
\text { Coefficients }\end{array}$ & \multirow{2}{*}{$\mathrm{t}$} & Sig. \\
\cline { 2 - 4 } & $\mathrm{B}$ & Std. Error & Beta & & \\
\hline 1 (Constant) & 16.636 & 7.931 & & 2.098 & .039 \\
Lingkungan Kerja & .292 & .128 & .237 & 2.278 & .025 \\
Motivasi Kerja & .402 & .096 & .433 & 4.17 & .000 \\
& & & & 5 & \\
\hline
\end{tabular}

a. Dependent Variable: Kepuasan Kerja

Berdasarkan Tabel 5, variabel lingkungan kerja memiliki nilai thitung sebesar 2.278. Nilai thitung kemudian dibandingkan dengan nilai tabel, yang dicari pada á $=5 \%: 2$ a t a u 2,5\% (uji 2 sisi) dengan derajat kebebasan (df) n-k-1 atau 85-2-1, di mana n adalah jumlah sampel dan $\mathrm{k}$ adalah jumlah variabel bebas. Berdasarkan perhitungan tersebut, didapat $t_{\text {tabel }}$ sebesar 1.989, dengan demikian thitung $<t_{\text {tabel }}$. Signifikansi pada variabel lingkungan kerja sebesar 0.025, dengan demikian lebih kecil dari 0.05. Kesimpulan yang dapat diambil, $\mathrm{H}_{\mathrm{o}}$ ditolak dan $\mathrm{H}_{\mathrm{a}}$ diterima. Dengan demikian lingkungan kerja memiliki pengaruh yang signifikan terhadap kepuasan kerja. Tabel 5 juga menunjukkan nilai thitung untuk variabel motivasi kerja sebesar 4.175, serta nilai signifikansi sebesar 0.000. Hal tersebut menunjukkan bahwa thitung $>t_{\text {tabel }}$ dan nilai signifikansi lebih kecil dari 0.05. Artinya, $\mathrm{HO}$ ditolak dan $\mathrm{H}_{\mathrm{a}}$ diterima. Dengan demikian, terdapat pengaruh yang signifikan antara motivasi kerja terhadap kepuasan kerja.

Model Persamaan Regresi Linear Berganda untuk H3. Berdasarkan Tabel 5, dapat diperoleh persamaan regresi linear berganda untuk hipotesis ketiga seperti berikut ini:

$$
\mathrm{Y}=16.636+0.292 \mathrm{X} 1+0.402 \mathrm{X} 2
$$


Konstanta pada model persamaan tersebut sebesar 16.636, dengan demikian, jika variabel lingkungan kerja (X1) dan motivasi kerja (X2) bernilai 0, maka variabel kepuasan kerja (Y) akan bernilai 16.636. Koefisien regresi variabel lingkungan kerja (X1) sebesar 0.292. Artinya, jika variabel lingkungan kerja (X1) ditingkatkan sebesar satu satuan dan nilai variabel motivasi kerja (X2) tetap, maka variabel kepuasan kerja (Y) akan mengalami kenaikan sebesar 0.292. Koefisien regresi variabel motivasi kerja (X2) sebesar 0.402. Artinya, jika variabel motivasi kerja (X2) mengalami kenaikan satu satuan dan nilai variabel lingkungan kerja (X1) tetap, maka variabel kepuasan kerja (Y) akan mengalami kenaikan sebesar 0.402. Koefisien pada kedua variabel bernilai positif, artinya terjadi pengaruh positif antara lingkungan kerja dan motivasi kerja terhadap kepuasan kerja karyawan.

Hasil Analisis Determinasi $\left(\mathbf{R}^{2}\right)$ untuk H3. Analisis koefisien determinasi $\left(\mathrm{R}^{2}\right)$ dalam regresi linear berganda digunakan untuk mengetahui seberapa besar persentase pengaruh sumbangan variabel bebas secara serentak terhadap variabel terikat. Hasil uji analisis koefisien determinasi dapat dilihat pada Tabel 6 .

Tabel 6. Hasil Analisis Determinasi H3 Model Summary

\begin{tabular}{crrrr}
\hline Model & $\mathrm{R}$ & R Square & $\begin{array}{c}\text { Adjusted R } \\
\text { Square }\end{array}$ & $\begin{array}{c}\text { Std. Error of the } \\
\text { Estimate }\end{array}$ \\
\hline 1 & $.591^{\mathrm{a}}$ & .349 & .333 & 10.807 \\
\hline
\end{tabular}

a. Predictors: (Constant), Motivasi Kerja, Lingkungan Kerja

Berdasarkan Tabel 6, nilai $\mathrm{R}^{2}$ yang tercantum sebesar 0,349. Dengan demikian, variabel lingkungan kerja dan motivasi kerja secara simultan memiliki persentase sumbangan pengaruh terhadap variabel kepuasan kerja sebesar 34.9\%. Sisanya, 65.1\% dijelaskan oleh faktor lain di luar penelitian.

Hasil Uji F. Dalam rangka menguji hipotesis ketiga, yaitu apakah terdapat pengaruh antara lingkungan kerja dan motivasi kerja secara bersama-sama atau simultan terhadap kepuasan kerja, maka perlu dilakukan uji F. Hasil uji F untuk hipotesis ketiga dapat dilihat pada Tabel 7 berikut.

Tabel 7. Hasil Uji F

ANOVA $^{\mathrm{b}}$

\begin{tabular}{|c|c|c|c|c|c|}
\hline Model & $\begin{array}{c}\text { Sum of } \\
\text { Squares }\end{array}$ & Df & $\begin{array}{c}\text { Mean } \\
\text { Square }\end{array}$ & F & Sig. \\
\hline 1 Regression & 5138.743 & 2 & 2569.371 & 22.001 & 000 \\
Residual & 9576.434 & 82 & 116.786 & & \\
Total & 14715.176 & 84 & & & \\
\hline
\end{tabular}

a. Predictors: (Constant), Motivasi Kerja, Lingkungan Kerja

b. Dependent Variable: Kepuasan Kerja

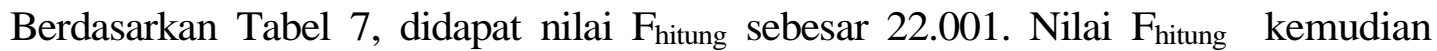

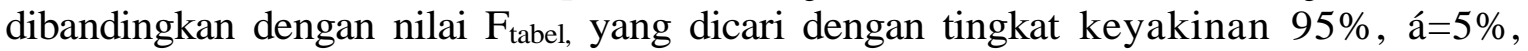
dengan df 1 (jumlah variabel-1) atau 3-1 2 , dan df2 (n-k-1) atau 85-2-1. Berdasarkan perhitungan tersebut, didapat $F_{\text {tabel }}$ sebesar 3.108, dengan demikian $F_{\text {hitung }}$

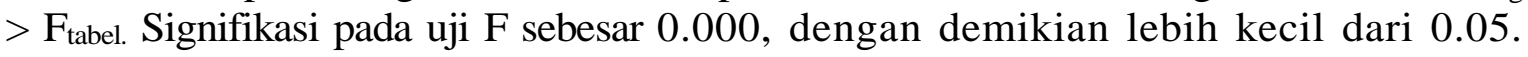


Kesimpulan yang dapat diambil, $\mathrm{H}_{\mathrm{o}}$ ditolak dan $\mathrm{H}_{\mathrm{a}}$ diterima. Hipotesisnya adalah lingkungan kerja dan motivasi kerja secara bersama-sama memiliki pengaruh yang signifikan terhadap kepuasan kerja.

Pembahasan. Hipotesis pertama ditolak. Artinya, lingkungan kerja mempunyai pengaruh yang signifikan terhadap kepuasan kerja. Hasil tersebut sama seperti hasil penelitian yang dilakukan oleh Vemmylia (2009), di mana hasil penelitian menunjukkan bahwa hubungan interpersonal dan lingkungan kerja memiliki hubungan yang sangat erat dilihat di $\mathrm{R}^{2}$ sebesar 0,700 atau $70 \%$. Demikian pula hasil penelitian lainya yang diteliti oleh Leonardus Bintoro (2010), di mana hasilnya juga menunjukkan bahwa terdapat pengaruh antara lingkungan kerja dengan kepuasan kerja dengan nilai koefisien regresi 0,450 .

Sementara itu, hasil $\mathrm{H}_{\mathrm{o}}$ untuk hipotesis kedua juga ditolak. Dengan demikian, motivasi kerja memiliki pengaruh yang signifikan terhadap kepuasan kerja. Hasil tersebut sama dengan hasil penelitian yang dilakukan oleh Mamik (2005), yang menunjukkan bahwa motivasi kerja berpengaruh terhadap kepuasan kerja. Demikian pula hasil penelitian lainnya yang diteliti oleh Rika Merlianti (2006) menunjukkan bahwa hasil analisis menyatakan motivasi kerja berpengaruh sebesar 34,81\% terhadap kepuasan kerja karyawan.

Model persamaan regresi linear sederhana untuk hipotesis pertama adalah $\mathrm{Y}=35.335+0.567 \mathrm{X} 1$, sedangkan untuk hipotesis kedua adalah $\mathrm{Y}=23.985+0.514 \mathrm{X} 2$ Berdasarkan persamaan tersebut, nilai koefisien regresi untuk variabel bebas pada masing-masing hipotesis bernilai positif atau sama-sama memiliki arah pengaruh yang selaras dengan variabel terikatnya, yaitu kepuasan kerja. Implikasinya, setiap peningkatan nilai tersebut sebesar satu satuan akan meningkatkan pula nilai variabel kepuasan kerja (Y).

Keseluruhan hasil dalam penelitian ini juga bisa terlihat pada hasil regresi linear berganda secara parsial untuk kedua variabel bebas. Analisis regresi linear berganda, $\mathrm{H}_{\mathrm{o}}$ pada hipotesis pertama ditolak. Artinya, lingkungan kerja memiliki pengaruh yang signifikan terhadap kepuasan kerja. Demikian juga $\mathrm{H}_{\mathrm{o}}$ pada hipotesis kedua ditolak. Artinya, motivasi kerja memiliki pengaruh yang signifikan terhadap kepuasan kerja.

Jika diinterpretasikan berdasarkan hasil analisis regresi linear $\mathrm{H}_{\mathrm{o}}$ pada hipotesis ketiga juga ditolak, sehingga membuktikan bahwa lingkungan kerja dan motivasi kerja secara simultan memiliki pengaruh yang signifikan terhadap kepuasan kerja. Hasil tersebut sesuai dengan hasil penelitian yang dilakukan Triningsih (2006) di mana hasil penelitiannya menunjukkan bahwa dari hasil uji parsial diperoleh thitung sebesar 3,734 dengan p-value $0,000<0,05$; yang berarti motivasi kerja berpengaruh positif terhadap kepuasan kerja. Lingkungan kerja dari hasil uji parsial diperoleh $t_{h i t u n g}$ 3,469 dengan $\mathrm{p}$-value $0,001<0,05$, yang berarti lingkungan kerja berpengaruh positif terhadap kepuasan kerja. Hasil uji simultan diperoleh $F_{\text {hitung }}$ 18,631 dengan p-value $0,000<0,05$, yang berarti secara bersama-sama motivasi kerja dan lingkungan kerja berpengaruh postif terhadap kepuasan kerja.

Model persamaan regresi linear berganda untuk hipotesis ketiga adalah $\mathrm{Y}=16.636$ $+0.292 \mathrm{X} 1+0.402 \mathrm{X} 2$, Artinya, kedua variabel bebas tersebut secara simultan memiliki arah pengaruh yang sama-sama positif terhadap satu variabel terikatnya, yaitu kepuasan kerja. Keseluruhan hasil dalam penelitian ini juga bisa terlihat pada hasil analisis regresi linear berganda secara parsial untuk kedua variabel bebas. Berdasarkan hasil analisis regresi linear maka $\mathrm{H}_{\mathrm{o}}$ pada hipotesis pertama ditolak. Artinya, gaya 
lingkungan kerja memiliki pengaruh yang signifikan terhadap kepuasan kerja. Sementara itu, $\mathrm{H}_{\mathrm{o}}$ pada hipotesis kedua ditolak. Artinya, motivasi kerja memiliki pengaruh yang signifikan terhadap kepuasan kerja.

\section{PENUTUP}

Simpulan. (1) Lingkungan kerja memiliki pengaruh yang signifikan terhadap kepuasan kerja. Artinya Lingkunagn kerja yang kondosif akan tercipta peningkatan kepuasan kerja. (2) Motivasi kerja memiliki pengaruh yang signifikan terhadap kepuasan kerja. Artinya motivasi yang tinggi akan dapat meningkatkan kepuasan kerja, (3) Lingkungan kerja dan motivasi kerja secara bersama-sama memiliki pengaruh yang signifikan terhadap kepuasan kerja; besarnya pengaruh adalah 34.9\%.

Saran. (1) Perlunya dilakukan penelitian lanjutan dengan memperhatikan variabel lain yang terkait yang sesuai dengan objek penelitian dan memperhatikan indikator yang digunakan para pakar. (2) Memperhatikan kepuasan kerja karyawan selain lingkungan kerja dan motivasi karyawan; untuk mengkaji ulang beberapa indikator seperti memperjelas kesesuaian gaji, pekerjaan itu sendiri, sistem promosi dan peluang karir, sehingga seluruh karyawan memiliki kesempatan yang sama; keinginan serta respon karyawan serta perasaan karyawan terhadap pekerjaan yang mereka lakukan, sehingga karyawan yang potensial tidak pindah dari Lembaga Pelayanan Publik TVRI.

\section{DAFTAR RUJUKAN}

Khoiriyah, Lilik. (2009) "Pengaruh Upah dan Lingkungan Kerja Terhadap Kinerja Karyawan pada CV. Aji Bali Jayawijaya Surakarta”. Fakultas Keguruan dan Ilmu Pendidikan, Tesis, Universitas Muhammadiyah Surakarta.

Nitisemito, Alex. (1992) Manajemen Personalia. Jakarta: Ghalia Indonesia.

Patty, Irene. (2007) "Lingkungan Kerja dan Evaluasi Manajemen Terhadap Kepuasan Kerja Karyawan pada Pemerintahan Daerah Kota Ambon”. Jurnal Eksekutif, 4 (2):78-85

Prabu, Anwar. (2005) "Pengaruh Motivasi Terhadap Kepuasan Kerja Pegawai Badan Koordinasi Keluarga Berencana Nasional Kabupaten Muara Enim”. Jurnal Manajemen dan Bisnis Sriwijaya, 3 (6): 115-123

Robbins, Stephen P. (2002) Prinsip-prinsip Perilaku Organisasi, Edisi kelima. Jakarta: PT. Gelora Aksara Pratama.

Robbins, Stephen P. dan Judge, Timothy A. (2008) Prilaku Organisasi, Edisi Keduabelas, Buku Satu. Jakarta: Salemba Empat.

Sekaran, Uma. (2007). Metode Penelitian untuk Bisnis, Edisi keempat, Buku satu. Jakarta: Salemba Empat.

Sudrajat. Kustiawan, Wawan dan Aipassa, Marlon. (1998) Manajemen Lingkungan Kerja. Direktorat Jenderal Pendidikan Tinggi Departemen Pendidikan dan Kebudayaan.

Surodilogo, Leonardus Bintoro. (2010) "Analisis Pengaruh Lingkungan Kerja dan Motivasi Kerja Terhadap Kepuasan Kerja Karyawan PT. Sumber Sehat Semarang”. Tesis, Fakultas Ekonomi Universitas Diponegoro Semarang. 
Surodilogo, Leonardus Bintoro. (2010) “Analisis Pengaruh Lingkungan Kerja dan Motivasi Kerja Terhadap Kepuasan Kerja Karyawan PT. Sumber Sehat Semarang”. Tesis.Fakultas Ekonomi Universitas Diponegoro Semarang.

Triningsih. (2006) "Pengaruh Motivasi Kerja dan Lingkungan Kerja terhadap Kepuasan Kerja Guru dan Karyawan SMP Negeri 30 Semarang Tahun Ajaran 2005/2006. Fakultas Ekonomi”. Tesis, Jurusan Manajemen Universitas Negeri Semarang.

Umar, Husein. (2008) Desain Penelitian MSDM dan Perilaku Karyawan. Jakarta: Raja Grafindo Persada.

Vemmylia. (2009) "Pengaruh Hubungan Interpersonal dan Lingkungan Kerja Terhadap Kepuasan Kerja karyawan pada PT. PLN Cabang Binjai”. Tesis, Fakultas Ekonomi Universitas Sumatera Utara Medan.

Wibowo. (2007) Manajemen Kinerja. Jakarta: PT. Raja Grafindo Persada.

Wahjono, Sentot Imam. (2008). Manajemen Tata kelola Organisasi Bisnis. Indonesia: PT. Indeks. 